Open Access

\title{
Chemical composition, energy and amino acid digestibility in double-low rapeseed meal fed to growing pigs
}

\author{
Peili Li ${ }^{1 \dagger}$, Fengli Wang ${ }^{1 \dagger}$, Fei Wu' ${ }^{1}$, Jinrong Wang ${ }^{2}$, Ling Liu ${ }^{1}$ and Changhua Lai ${ }^{1 *}$
}

\begin{abstract}
Background: The nutritional value of rapeseed meal may be variable due to the variation of its chemical composition. And a precise understanding of the nutritional value of an ingredient is beneficial for the accurate diet formulation and reduction of feed costs. This study was conducted to determine the chemical composition, digestible energy (DE) and metabolizable energy (ME) content, and apparent ileal digestibility (AID) and standardized ileal digestibility (SID) of amino acids (AA) for growing pigs. Thirteen solvent-extracted double-low rapeseed meal (DLRSM) samples were obtained from the main double-low rapeseed producing areas in China.
\end{abstract}

Methods: The DE and ME contents of the 13 DLRSM samples were measured in growing pigs (six pigs per DLRSM sample, average initial body weight $(B W)=48.3 \mathrm{~kg}$ ). The AID and SID of AA of 10 DLRSM samples were determined in 12 crossbred barrows (average initial BW $=35.3 \mathrm{~kg}$ ) by using two $6 \times 6$ Latin square designs. Each Latin square comprised one N-free diet and 5 DLRSM test diets.

Results: The chemical composition of DLRSM varied among samples, and the coefficient of variation was greater than $10 \%$ for ether extract (EE), neutral detergent fiber (NDF), acid detergent fiber (ADF), calcium (Ca), and total glucosinolates. The AA content of DLRSM varied among samples especially for lysine (Lys) and methionine (Met). On a dry matter (DM) basis, the apparent total tract digestibility (ATTD) of gross energy (GE), the DE and ME and the ME:DE ratio of DLRSM averaged $62.39 \%, 2862 \mathrm{kcal} / \mathrm{kg}$ and $2723 \mathrm{kcal} / \mathrm{kg}$, and $94.95 \%$, respectively. The mean value of SID of Lys was $70.52 \%$ which varied from $66.54-76.54 \%$. The SID of crude protein (CP), Met, and threonine (Thr) averaged $72.81 \%, 82.41 \%$, and $69.76 \%$, respectively.

Conclusions: There was great variability in chemical composition especially in the concentration of EE, NDF and ADF, but no significant differences in energy content of the DLRSM samples were observed. In addition, the AID and SID of all AA were relatively similar among DLRSM samples except for that of Lys.

Keywords: Digestible energy, Double-low rapeseed meal, Growing pigs, lleal digestibility of amino acids,

Metabolizable energy

\section{Background}

Double-low rapeseed meal (DLRSM), a by-product of solvent-extracted rapeseed oil production, is a potential source of vegetable protein for use in swine diets. Double-low rapeseed contains less than $2 \%$ erucic acid in the oil and less than $30 \mu \mathrm{mol} / \mathrm{g}$ glucosinolates in the meal, whereas rapeseed contains $25-45 \%$ erucic acid in

\footnotetext{
*Correspondence: laichanghua999@163.com

${ }^{\dagger}$ Equal contributors

${ }^{1}$ State Key Laboratory of Animal Nutrition, College of Animal Science and Technology, China Agricultural University, Beijing 100193, China

Full list of author information is available at the end of the article
}

the oil and $50-100 \mu \mathrm{mol} / \mathrm{g}$ glucosinolates in the meal [1]. The superiority of DLRSM over rapeseed meal as a protein supplement is well known [2].

The nutritional value of DLRSM has been discussed [2], determined in many countries [3-6] and also included in the NRC [7]. However, the nutritional value of DLRSM in China is expected to be different compared with that of other countries due to the variation in varieties, seed quality, soil conditions, and processing conditions [1].

Although the variety of DLRSM in China is almost always Brassica napus, the difference within the species

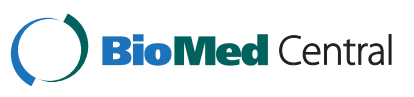


may lead to the variation of the quality of DLRSM. On the other hand, the temperature and time control in processing especially during desolventizing and toasting vary among different DLRSM plants in China; the heat treatment during this stage is critical for the quality of protein in DLRSM $[8,9]$. In China, several researches for the nutritional value of rapeseed meal have been done [10-12], whereas little research has been done on DLRSM. So more information on the nutritional value of DLRSM produced in China is needed for diet formulation. Therefore, the objective of this study was to investigate the variation of the chemical composition, energy content and ileal amino acids (AA) digestibility of DLRSM.

\section{Methods}

\section{General}

All animal experimentation procedures were approved by the Institutional Animal Care and Use Committee at China Agricultural University (Beijing, China). Two experiments were conducted in the Metabolism Laboratory of the Ministry of Agriculture Feed Industry Centre (China Agricultural University, Beijing, China). The DLRSM samples were obtained from the main double-low rapeseed producing areas in China. All samples were solvent-extracted DLRSM. Thirteen meals were selected from the collected 20 DLRSM to achieve the greatest variability (Table 1). However, only 10 of the collected 20 DLRSM were selected to determine their ileal AA digestibility. The chemical composition and AA content of these DLRSM are shown in Tables 2 and 3. The diets in both experiments were all fed as mash. The pigs were fed the diets equal to $4 \%$ of their body weight (BW) and the daily feed allowance [13] was offered in two

Table 1 Source of double-low rapeseed meals used in the two experiments

\begin{tabular}{ll}
\hline Number & City and Province in China \\
\hline 1 & Quyuan, Hunan \\
2 & Lixian, Hunan \\
3 & Luliang, Hunan \\
4 & Xidongting, Hunan \\
5 & Yingcheng, Hunan \\
6 & Yiyang, Hunan \\
7 & Huaihua, Hunan \\
8 & Xiaodukou, Hunan \\
9 & Feixi, Anhui \\
10 & Jingzhou, Hubei \\
11 & Yichang, Hubei \\
12 & Gong'an, Hubei \\
13 & Huanggang, Hubei \\
\hline
\end{tabular}

equal meals at 0800 and $1700 \mathrm{~h}$. Water was freely available at all times throughout the experiment. The barrows were individually placed in stainless-steel metabolism crates $(1.4 \mathrm{~m} \times 0.45 \mathrm{~m} \times 0.6 \mathrm{~m})$ in a temperaturecontrolled room $\left(22 \pm 2{ }^{\circ} \mathrm{C}\right)$. The pigs used in both experiments were crossbred (Duroc $\times$ Landrace $\times$ Yorkshire) barrows obtained from Fengning Swine Research Unit, China Agricultural University (Beijing, China).

\section{Exp. 1: Energy digestibility}

This experiment was conducted to determine the apparent total tract digestibility (ATTD) of gross energy (GE), the digestible energy (DE) and metabolizable energy (ME) and the ME:DE ratio of 13 DLRSM fed to growing pigs. Eighty-four crossbred barrows (initial BW: $48.3 \pm 2.4 \mathrm{~kg}$; Duroc $\times$ Landrace $\times$ Yorkshire) were allocated to one of 14 dietary treatments in a completely randomized design with 6 barrows in each dietary treatment. The 14 experimental diets included one corn-soybean meal basal diet and 13 DLRSM test diets. The DLRSM test diets were formulated to contain $19.2 \%$ DLRSM which replaced $20 \%$ of the energy supplied by corn, soybean meal, and Lys in the basal diet (Table 4). The chemical composition of the experimental diets is presented in Table 5.

The experiment lasted $14 \mathrm{~d}$ which comprised 9-d for adaptation to the diets followed by a 5 -d total collection of feces and urine. Feces were collected into bags (one pig per bag) immediately when it appeared in the metabolism crates and stored at $-20{ }^{\circ} \mathrm{C}$. Urine was collected in buckets located under the metabolism crates. The buckets contain $50 \mathrm{~mL}$ of $6 \mathrm{~N} \mathrm{HCl}$ and the urine was measured by volume every morning. A sample $(10 \%$ of the total volume) was collected, and after filtering, the urine samples were stored at $-20^{\circ} \mathrm{C}$. The collection procedures were conducted according to the methods described by Song et al. [14] and Ren et al. [15].

\section{Exp. 2: Amino acid digestibility}

This experiment was conducted to determine the apparent ileal digestibility (AID) and standardized ileal digestibility (SID) of crude protein (CP) and AA in 10 samples of DLRSM (numbers 1-5, 8, 10-12; Table 1) fed to growing pigs. Twelve crossbred barrows (initial BW: $35.3 \pm 3.8 \mathrm{~kg}$; Duroc $\times$ Landrace $\times$ Yorkshire) with a Tcannula near the distal ileum were assigned to one of two $6 \times 6$ Latin square designs. Each Latin square comprised one $\mathrm{N}$-free diet and 5 DLRSM test diets. The test diets contained $40 \%$ of one of the 10 DLRSM as the sole source of protein, and the $\mathrm{N}$-free diet was formulated according to the methods described by Stein et al. [16] to estimate the basal endogenous losses of $\mathrm{CP}$ and $\mathrm{AA}$ for determining the SID of CP and AA (Table 4). The chemical composition of the Exp. 2 diets is presented in Table 6. The procedure of equipping the pig with a T-cannula near the distal ileum 
Table 2 Analyzed proximate composition (\% of dry matter, unless otherwise indicated) of double-low rapeseed meals

\begin{tabular}{|c|c|c|c|c|c|c|c|c|c|c|c|c|c|c|c|c|c|}
\hline \multirow[t]{2}{*}{ Item } & \multicolumn{13}{|c|}{ Double-low rapeseed meal number ${ }^{a}$} & \multirow[b]{2}{*}{ Mean } & \multirow[b]{2}{*}{ Maximum } & \multirow[b]{2}{*}{ Minimum } & \multirow[b]{2}{*}{$C V^{b}$} \\
\hline & 1 & 2 & 3 & 4 & 5 & 6 & 7 & 8 & 9 & 10 & 11 & 12 & 13 & & & & \\
\hline Dry matter & 90.14 & 90.06 & 89.90 & 88.71 & 89.16 & 89.90 & 90.11 & 90.30 & 89.89 & 89.82 & 89.28 & 89.19 & 90.66 & 89.78 & 90.66 & 88.71 & 0.61 \\
\hline Crude protein & 42.67 & 43.59 & 41.35 & 43.64 & 42.26 & 42.55 & 42.97 & 43.29 & 39.57 & 43.02 & 40.29 & 41.48 & 39.37 & 42.00 & 43.64 & 39.37 & 3.51 \\
\hline Ether extract & 1.52 & 0.70 & 1.32 & 1.59 & 1.47 & 1.62 & 1.67 & 1.27 & 1.98 & 1.37 & 1.79 & 1.42 & 1.73 & 1.50 & 1.98 & 0.70 & 20.88 \\
\hline Crude fiber & 15.15 & 15.14 & 14.48 & 12.73 & 13.50 & 15.35 & 17.26 & 13.16 & 12.60 & 13.41 & 14.81 & 14.15 & 15.08 & 14.37 & 17.26 & 12.6 & 9.03 \\
\hline Neutral detergent fibre & 40.35 & 40.33 & 35.31 & 29.90 & 32.20 & 27.91 & 39.46 & 39.24 & 38.74 & 39.21 & 40.98 & 31.31 & 38.13 & 36.39 & 40.98 & 27.91 & 12.41 \\
\hline Acid detergent fibre & 28.20 & 27.64 & 21.29 & 22.30 & 22.25 & 18.80 & 24.24 & 27.36 & 23.92 & 21.08 & 25.84 & 23.85 & 22.61 & 23.80 & 28.20 & 18.8 & 11.88 \\
\hline Ash & 8.78 & 8.28 & 8.53 & 7.72 & 8.05 & 7.15 & 7.92 & 9.13 & 9.63 & 8.48 & 8.18 & 8.09 & 10.06 & 8.46 & 10.06 & 7.15 & 9.31 \\
\hline Calcium & 0.94 & 0.90 & 0.98 & 0.83 & 0.88 & 0.81 & 0.74 & 0.92 & 0.69 & 1.08 & 0.79 & 0.95 & 0.90 & 0.88 & 1.08 & 0.69 & 12.05 \\
\hline Phosphorus & 0.90 & 0.86 & 0.93 & 0.95 & 0.89 & 0.97 & 0.92 & 0.93 & 0.82 & 0.95 & 0.86 & 1.04 & 0.89 & 0.92 & 1.04 & 0.82 & 6.33 \\
\hline Gross energy, kcal/kg & 4575 & 4568 & 4542 & 4636 & 4585 & 4707 & 4650 & 4557 & 4499 & 4587 & 4592 & 4645 & 4508 & 4589 & 4707 & 4499 & 1.28 \\
\hline Total glucosinolates, $\mu \mathrm{mol} / \mathrm{g}$ & 5.57 & 6.58 & 5.11 & 4.15 & 9.83 & 7.02 & 16.83 & 10.04 & 5.29 & 20.08 & 6.59 & 22.73 & 11.11 & 10.07 & 22.73 & 4.15 & 60.37 \\
\hline
\end{tabular}

${ }^{a}$ Sources of double-low rapeseed meal are described in Table 1

${ }^{\mathrm{b}} \mathrm{CV}$ coefficient of variation 
Table 3 Analyzed AA composition of double-low rapeseed meals (\% of dry matter)

\begin{tabular}{|c|c|c|c|c|c|c|c|c|c|c|c|c|c|}
\hline \multirow[t]{2}{*}{ Item } & \multicolumn{9}{|c|}{ Double-low rapeseed meal number ${ }^{a}$} & \multirow[b]{2}{*}{ Mean } & \multirow[b]{2}{*}{ Maximum } & \multirow[b]{2}{*}{ Minimum } & \multirow[b]{2}{*}{$\mathrm{CV}^{\mathrm{b}}$} \\
\hline & 1 & 2 & 3 & 4 & 5 & 8 & 10 & 11 & 12 & & & & \\
\hline Crude protein & 42.67 & 43.59 & 41.35 & 43.64 & 42.26 & 43.29 & 43.02 & 40.29 & 41.48 & 42.40 & 43.64 & 40.29 & 2.72 \\
\hline \multicolumn{14}{|c|}{ Indispensable AA } \\
\hline $\operatorname{Arg}$ & 2.18 & 2.23 & 2.14 & 2.41 & 2.31 & 2.19 & 2.27 & 2.08 & 2.22 & 2.23 & 2.41 & 2.08 & 4.35 \\
\hline His & 1.05 & 1.06 & 1.04 & 1.20 & 1.14 & 1.13 & 1.13 & 1.06 & 1.09 & 1.10 & 1.20 & 1.04 & 4.83 \\
\hline Ile & 1.52 & 1.51 & 1.42 & 1.56 & 1.51 & 1.51 & 1.48 & 1.38 & 1.41 & 1.48 & 1.56 & 1.38 & 4.03 \\
\hline Leu & 2.67 & 2.67 & 2.55 & 2.76 & 2.65 & 2.65 & 2.68 & 2.47 & 2.54 & 2.63 & 2.76 & 2.47 & 3.38 \\
\hline Lys & 1.96 & 1.94 & 2.02 & 2.41 & 2.25 & 1.97 & 2.06 & 1.95 & 2.21 & 2.09 & 2.41 & 1.94 & 7.92 \\
\hline Met & 0.86 & 0.91 & 0.94 & 0.97 & 0.91 & 0.94 & 1.00 & 0.77 & 0.76 & 0.90 & 1.00 & 0.76 & 9.46 \\
\hline Phe & 1.34 & 1.36 & 1.28 & 1.36 & 1.31 & 1.31 & 1.31 & 1.22 & 1.27 & 1.31 & 1.36 & 1.22 & 3.59 \\
\hline Thr & 1.84 & 1.86 & 1.80 & 1.91 & 1.79 & 1.79 & 1.86 & 1.76 & 1.81 & 1.82 & 1.91 & 1.76 & 2.50 \\
\hline Trp & 0.51 & 0.54 & 0.50 & 0.53 & 0.52 & 0.51 & 0.52 & 0.46 & 0.50 & 0.51 & 0.54 & 0.46 & 4.49 \\
\hline Val & 2.34 & 2.35 & 2.17 & 2.38 & 2.28 & 2.28 & 2.24 & 2.15 & 2.19 & 2.26 & 2.38 & 2.15 & 3.66 \\
\hline \multicolumn{14}{|c|}{ Dispensable AA } \\
\hline Ala & 1.75 & 1.75 & 1.76 & 2.05 & 1.96 & 1.97 & 1.98 & 1.86 & 1.90 & 1.89 & 2.05 & 1.75 & 5.95 \\
\hline Asp & 2.77 & 2.82 & 2.74 & 2.93 & 2.80 & 2.82 & 2.87 & 2.60 & 2.72 & 2.79 & 2.93 & 2.60 & 3.42 \\
\hline Cys & 1.15 & 1.18 & 1.19 & 1.24 & 1.22 & 1.11 & 1.19 & 1.14 & 1.15 & 1.17 & 1.24 & 1.11 & 3.60 \\
\hline Glu & 6.98 & 7.01 & 6.68 & 7.41 & 7.12 & 7.16 & 7.30 & 6.67 & 6.82 & 7.02 & 7.41 & 6.67 & 3.73 \\
\hline Gly & 2.51 & 2.52 & 2.30 & 2.36 & 2.26 & 2.27 & 2.32 & 2.15 & 2.21 & 2.32 & 2.52 & 2.15 & 5.38 \\
\hline Pro & 2.25 & 2.10 & 2.05 & 2.46 & 2.35 & 2.33 & 2.36 & 2.24 & 2.30 & 2.27 & 2.46 & 2.05 & 5.76 \\
\hline Ser & 1.71 & 1.73 & 1.66 & 1.75 & 1.65 & 1.63 & 1.73 & 1.62 & 1.66 & 1.68 & 1.75 & 1.62 & 2.81 \\
\hline Tyr & 0.74 & 0.77 & 0.68 & 0.81 & 0.77 & 0.76 & 0.76 & 0.76 & 0.75 & 0.75 & 0.81 & 0.68 & 5.36 \\
\hline
\end{tabular}

Sources of double-low rapeseed meal are described in Table 1

${ }^{\mathrm{b}} \mathrm{CV}$ coefficient of variation

was according to the method described by Stein et al. [17]. (1998). Each of the six periods in the Latin square design lasted $7 \mathrm{~d}$ within which the first $5 \mathrm{~d}$ were for adaptation and the last $2 \mathrm{~d}$ for ileal digesta collection. Ileal digesta were collected continuously from $0800-1700 \mathrm{~h}$. The collection procedures used followed the description provided by Stein et al. [17]. Briefly, on d 6 and 7, a $200 \mathrm{~mL}$ plastic bag was attached to the open cannula using a cable tie. The bags were removed whenever they were filled with digesta or at least every $30 \mathrm{~min}$ and stored at $-20{ }^{\circ} \mathrm{C}$ until required for analysis.

\section{Sample preparation and chemical analyses}

Fecal samples were dried in an oven at $65{ }^{\circ} \mathrm{C}$ for three days, weighed, pooled for each pig and subsampled. Ileal digesta samples were thawed, mixed within pig and period, subsampled and lyophilized in a vacuum-freeze dryer (Tofflon Freezing Drying Systems, Shanghai, China). Samples of DLRSM, diets, feces, and ileal digesta were ground through a 1-mm screen and thoroughly mixed for analysis. Urine samples were thawed and thoroughly mixed within pig for analysis.

Samples of DLRSM, diets, feces, and digesta was analysed for dry matter (DM) (procedure 930.15) [18]. All
DLRSM samples and diets in Exp. 1 were analyzed for CP (procedure 984.13), ash (procedure, 942.05), calcium (procedure 968.08), phosphorus (procedure 946.06), and crude fiber (CF) (procedure 978.10) [18]. Ether extract (EE) were determined according to the method of Thiex et al. [19] and Kjeldahl $\mathrm{N}$ was determined according to the method of Thiex et al. [20]. The concentrations of neutral detergent fiber (NDF) and acid detergent fiber (ADF) were determined according to the method of Van Soest et al. [21]. The concentration of NDF was analyzed using heat-stable $\alpha$-amylase and sodium sulfite without correction for insoluble ash as adapted for an Ankom Fiber Analyzer (Ankom Technology, Macedon, NY). The ADF fraction was analyzed in a separate sample. The concentration of total glucosinolates was analyzed according to Daun et al. [22]. Samples of DLRSM, diets, feces, and urine were analyzed for gross energy via an adiabatic oxygen bomb calorimeter (Parr Instruments Co., Moline, IL).

Samples of DLRSM, diets, and ileal digesta from Exp. 2 were hydrolyzed with $6 \mathrm{~N} \mathrm{HCl}$ for $24 \mathrm{~h}$ at $110{ }^{\circ} \mathrm{C}$ [18] and analyzed for 15 AA using an Amino Acid Analyzer (Hitachi L-8900, Tokyo, Japan). The sulfur-containing AA, methionine (Met) and cysteine 
Table 4 Ingredient composition of experimental diets (as-fed basis, \%)

\begin{tabular}{|c|c|c|c|c|}
\hline \multirow[t]{2}{*}{ Item } & \multicolumn{2}{|c|}{ Exp. 1} & \multicolumn{2}{|l|}{ Exp. 2} \\
\hline & $\begin{array}{l}\text { Basal } \\
\text { diet }\end{array}$ & $\begin{array}{l}\text { Test } \\
\text { diets }\end{array}$ & $\begin{array}{l}\text { Double-low } \\
\text { rapeseed meal diets }\end{array}$ & $\begin{array}{l}\mathrm{N} \text {-free } \\
\text { diet }\end{array}$ \\
\hline Corn & 77.40 & 61.90 & - & - \\
\hline Soybean meal & 18.60 & 14.90 & - & - \\
\hline Double-low rapeseed meal & - & 19.20 & 40.00 & - \\
\hline Cornstarch & - & - & 34.40 & 68.90 \\
\hline Sucrose & - & - & 20.00 & 20.00 \\
\hline Cellulose acetate ${ }^{a}$ & - & - & - & 4.00 \\
\hline Soybean oil & - & - & 3.00 & 3.00 \\
\hline L-lysine $\cdot \mathrm{HCl}^{b}$ & 0.10 & 0.08 & - & - \\
\hline Dicalcium phosphate & 1.20 & 1.20 & 1.00 & 1.60 \\
\hline Potassium carbonate & - & - & - & 0.30 \\
\hline Magnesium oxide & - & - & - & 0.10 \\
\hline Limestone & 1.10 & 1.10 & 0.50 & 1.00 \\
\hline Wheat rice stone ${ }^{c}$ & 0.80 & 0.80 & - & - \\
\hline Vitamin-mineral premix ${ }^{d}$ & 0.50 & 0.50 & 0.50 & 0.50 \\
\hline Salt & 0.30 & 0.30 & 0.30 & 0.30 \\
\hline Chromic oxide & - & - & 0.30 & 0.30 \\
\hline
\end{tabular}

${ }^{a}$ Made by Chemical Reagents Company, Beijing, China

${ }^{b}$ Made by Dacheng Group, Jilin, China

'Used as carrier for L-lysine $\cdot \mathrm{HCl}$ and contained more than $70 \%$ silicon oxide and aluminium oxide, made by YiXian BeiQiao Tou Ore Company (YiXian, China)

dProvided the following quantities of vitamins and minerals per $\mathrm{kg}$ of complete diet: $\mathrm{Mn}, 50 \mathrm{mg}(\mathrm{MnO}) ; \mathrm{Fe}, 125 \mathrm{mg}\left(\mathrm{FeSO}_{4} \cdot \mathrm{H}_{2} \mathrm{O}\right) ; \mathrm{Zn}, 125 \mathrm{mg}(\mathrm{ZnO})$; $\mathrm{Cu}, 150 \mathrm{mg}\left(\mathrm{CuSO}_{4} \cdot 5 \mathrm{H}_{2} \mathrm{O}\right) ; \mathrm{l}, 50 \mathrm{mg}\left(\mathrm{Cal}_{2}\right) ; \mathrm{Se}, 0.30 \mathrm{mg}\left(\mathrm{Na}_{2} \mathrm{SeO}_{3}\right)$, retinyl acetate, $4500 \mathrm{IU}$; cholecalciferol, $1350 \mathrm{IU}$; DL-a-tocopheryl acetate, $13.5 \mathrm{mg}$; menadione sodium bisulfite complex, $2.7 \mathrm{mg}$; niacin, $18 \mathrm{mg}$; vitamin $\mathrm{B}_{12}$, $27.6 \mu \mathrm{g}$; thiamine, $0.6 \mathrm{mg}$; pyridoxine, $0.9 \mathrm{mg}$; riboflavin, $1.8 \mathrm{mg}$; D-calciumpantothenate, $10.8 \mathrm{mg}$; nicotinic acid, $30.3 \mathrm{mg}$; choline chloride, $210 \mathrm{mg}$
(Cys), were subjected to performic acid oxidation and hydrolyzed with $7.5 \mathrm{~N} \mathrm{HCl}$ for $24 \mathrm{~h}$ at $110{ }^{\circ} \mathrm{C}$ [18] before measurement using an Amino Acid Analyzer (Hitachi L-8800, Tokyo, Japan). Tryptophan (Trp) was determined after $\mathrm{LiOH}$ hydrolysis for $22 \mathrm{~h}$ at $110{ }^{\circ} \mathrm{C}$ [18] using High Performance Liquid Chromatography (Agilent 1200 Series, Santa Clara, CA). The chromium $(\mathrm{Cr})$ concentration of diets and ileal digesta samples was determined after nitric acid-perchloric acid wet ash sample preparation using a Polarized Zeeman Atomic Absorption Spectrometer (Hitachi Z2000, Tokyo, Japan).

\section{Calculations}

In Exp. 1, the DE and ME of 13 DLRSM were determined. The ATTD of GE as well as DE and ME content of the DLRSM were calculated using the difference method [13].

In Exp. 2, the AA digestibility of DLRSM samples was calculated as described by Stein et al. [16]. Because DLRSM was the only feed ingredient contributing AA in the experimental diets, dietary values also represent the digestibility for each sample of DLRSM. The AID of AA in the diets containing DLRSM was calculated according to the following equation:

$$
\mathrm{AID}=\left[1-\left(A A_{\text {digesta }} / A A_{\text {diet }}\right) \times\left(C r_{\text {diet }} / C r_{\text {digesta }}\right)\right] \times 100 \%,
$$

where AID is the apparent ileal digestibility of an AA (\%), $\mathrm{AA}_{\text {digesta }}$ is the $\mathrm{AA}$ concentration in the ileal digesta $(\mathrm{g} / \mathrm{kg}$ of $\mathrm{DM}), \mathrm{AA}_{\text {diet }}$ is the $\mathrm{AA}$ concentration in the diets $(\mathrm{g} / \mathrm{kg}$ of $\mathrm{DM}), \mathrm{Cr}_{\text {diet }}$ is the chromium concentration in the diet $(\mathrm{g} / \mathrm{kg}$ of $\mathrm{DM})$, and $\mathrm{Cr}_{\text {digesta }}$ is the chromium concentration in the ileal digesta $(\mathrm{g} / \mathrm{kg}$ of $\mathrm{DM})$. The AID of CP was calculated using the equation above.

Table 5 Analyzed composition of the experimental diets used in Exp. 1 (\% as-fed basis)

\begin{tabular}{|c|c|c|c|c|c|c|c|c|c|c|c|c|c|c|}
\hline \multirow[t]{2}{*}{ Diet } & \multirow{2}{*}{$\begin{array}{l}\text { Basal } \\
\text { diet }\end{array}$} & \multicolumn{13}{|c|}{ Test diets ${ }^{\mathrm{a}}$} \\
\hline & & 1 & 2 & 3 & 4 & 5 & 6 & 7 & 8 & 9 & 10 & 11 & 12 & 13 \\
\hline Dry matter & 89.15 & 89.66 & 89.64 & 89.64 & 89.41 & 89.65 & 89.74 & 89.87 & 89.79 & 90.05 & 89.53 & 89.50 & 89.46 & 89.60 \\
\hline Crude protein & 15.19 & 19.13 & 19.06 & 18.78 & 19.59 & 19.29 & 18.91 & 19.52 & 19.61 & 18.90 & 19.40 & 18.51 & 18.70 & 18.77 \\
\hline Ether extract & 1.98 & 2.34 & 2.20 & 2.12 & 1.84 & 1.86 & 1.93 & 2.02 & 1.94 & 1.88 & 2.10 & 2.05 & 2.01 & 1.94 \\
\hline Crude fiber & 1.95 & 4.30 & 4.41 & 4.31 & 4.00 & 4.11 & 3.94 & 4.01 & 4.05 & 4.27 & 4.07 & 4.26 & 4.29 & 4.01 \\
\hline Neutral detergent fibre & 10.14 & 18.99 & 15.31 & 15.41 & 14.90 & 15.51 & 15.21 & 16.75 & 16.28 & 16.76 & 16.17 & 16.31 & 15.35 & 16.48 \\
\hline Acid detergent fibre & 3.12 & 8.36 & 6.11 & 6.90 & 6.73 & 6.87 & 6.57 & 6.85 & 7.13 & 7.39 & 6.92 & 7.25 & 7.07 & 7.07 \\
\hline Ash & 5.46 & 6.51 & 6.28 & 6.33 & 6.09 & 6.34 & 6.26 & 6.13 & 6.49 & 6.48 & 6.41 & 6.30 & 6.31 & 6.97 \\
\hline Calcium & 0.64 & 0.79 & 0.77 & 0.77 & 0.76 & 0.73 & 0.69 & 0.67 & 0.78 & 0.69 & 0.81 & 0.36 & 0.82 & 0.79 \\
\hline Phosphorus & 0.58 & 0.65 & 0.68 & 0.69 & 0.68 & 0.69 & 0.68 & 0.67 & 0.68 & 0.68 & 0.69 & 0.33 & 0.69 & 0.69 \\
\hline Gross energy, kcal/kg & 3786 & 3817 & 3841 & 3826 & 3830 & 3816 & 3836 & 3829 & 3820 & 3815 & 3818 & 3823 & 3821 & 3797 \\
\hline
\end{tabular}

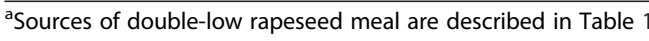


Table 6 Analyzed composition of the experimental diets used in Exp. 2 (\% as-fed basis)

\begin{tabular}{|c|c|c|c|c|c|c|c|c|c|c|}
\hline \multirow[t]{2}{*}{ Item } & \multicolumn{9}{|c|}{ Double-low rapeseed meal diets ${ }^{a}$} & \multirow{2}{*}{$\begin{array}{l}\mathrm{N} \text {-free } \\
\text { diet }\end{array}$} \\
\hline & 1 & 2 & 3 & 4 & 5 & 8 & 10 & 11 & 12 & \\
\hline Dry matter & 93.50 & 92.65 & 92.78 & 92.70 & 93.21 & 93.17 & 93.17 & 93.16 & 92.89 & 92.45 \\
\hline Crude protein & 16.40 & 16.11 & 15.34 & 15.33 & 15.92 & 15.73 & 15.23 & 14.64 & 15.29 & 0.87 \\
\hline \multicolumn{11}{|c|}{ Indispensable AA } \\
\hline $\operatorname{Arg}$ & 0.84 & 0.97 & 0.82 & 0.85 & 0.75 & 0.75 & 0.76 & 0.62 & 0.73 & - \\
\hline His & 0.40 & 0.46 & 0.39 & 0.41 & 0.41 & 0.40 & 0.39 & 0.38 & 0.38 & - \\
\hline Ile & 0.69 & 0.75 & 0.66 & 0.64 & 0.64 & 0.65 & 0.63 & 0.59 & 0.63 & - \\
\hline Leu & 1.07 & 1.18 & 1.02 & 1.03 & 0.98 & 1.00 & 1.00 & 0.90 & 0.96 & - \\
\hline Lys & 0.72 & 0.83 & 0.75 & 0.83 & 0.82 & 0.71 & 0.75 & 0.71 & 0.80 & - \\
\hline Met & 0.26 & 0.27 & 0.25 & 0.25 & 0.27 & 0.24 & 0.26 & 0.23 & 0.25 & - \\
\hline Phe & 0.56 & 0.65 & 0.53 & 0.54 & 0.60 & 0.56 & 0.55 & 0.57 & 0.56 & - \\
\hline Thr & 0.63 & 0.73 & 0.63 & 0.65 & 0.65 & 0.64 & 0.62 & 0.61 & 0.63 & - \\
\hline Trp & 0.18 & 0.18 & 0.16 & 0.17 & 0.19 & 0.18 & 0.18 & 0.18 & 0.17 & - \\
\hline Val & 0.80 & 0.89 & 0.74 & 0.74 & 0.83 & 0.77 & 0.79 & 0.77 & 0.78 & - \\
\hline \multicolumn{11}{|l|}{ Dispensable AA } \\
\hline Ala & 0.66 & 0.75 & 0.62 & 0.64 & 0.69 & 0.66 & 0.67 & 0.62 & 0.66 & - \\
\hline Asp & 1.01 & 1.16 & 1.00 & 1.02 & 1.03 & 1.02 & 1.00 & 0.90 & 0.98 & - \\
\hline Cys & 0.36 & 0.36 & 0.35 & 0.32 & 0.37 & 0.30 & 0.33 & 0.30 & 0.33 & - \\
\hline Glu & 2.55 & 2.93 & 2.44 & 2.50 & 2.55 & 2.51 & 2.43 & 2.30 & 2.41 & - \\
\hline Gly & 0.74 & 0.84 & 0.71 & 0.72 & 0.75 & 0.73 & 0.72 & 0.68 & 0.71 & - \\
\hline Pro & 0.93 & 1.07 & 0.99 & 0.87 & 0.88 & 0.93 & 0.86 & 0.82 & 0.87 & - \\
\hline Ser & 0.59 & 0.70 & 0.60 & 0.63 & 0.61 & 0.62 & 0.61 & 0.56 & 0.60 & - \\
\hline Tyr & 0.76 & 0.81 & 0.77 & 0.75 & 0.69 & 0.68 & 0.71 & 0.67 & 0.68 & - \\
\hline
\end{tabular}

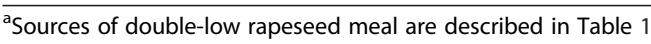

The IAA ${ }_{\text {end }}$ of AA for each pig fed the $\mathrm{N}$-free diet was determined according to following equation:

$$
I A A_{\text {end }}=\left[A A_{\text {digesta }} \times\left(C r_{\text {diet }} / C r_{\text {digesta }}\right)\right],
$$

where $\mathrm{IAA}_{\text {end }}$ is the basal ileal endogenous loss of an AA ( $\mathrm{g} / \mathrm{kg}$ of DM intake). The endogenous loss of CP was also determined using the same equation.

By correcting the AID of each AA, which was calculated for each sample for the IAA $A_{\text {end }}$ of each AA, the SID of AA was corrected according to following equation:

$$
S I D=\left[\text { AID }+\left(I A A_{\text {end }} / A A_{\text {diet }}\right) \times 100\right],
$$

where SID is the standardized ileal digestibility of an AA (\%).

\section{Statistical analyses}

The data for the ATTD of GE, the DE and ME content, the ME:DE ratio were analyzed using the GLM procedure (SAS Institute Inc., Cary, NC), with the pig as the experimental unit. The data on AID and SID were analyzed using the ANOVA procedure with DLRSM source, pig, and period as the main effects. The total variation was analyzed by the model described by Ji et al. [23]. In all analyses, the differences were considered significant if $P<0.05$.

\section{Results}

Chemical composition of DLRSM

The chemical composition of the 13 DLRSM is presented in Table 2, and the chemical composition of the experimental diets is presented in Table 5. The chemical composition of DLRSM varied among samples, whereas the coefficient of variation was greater than $10 \%$ for ether extract, NDF, ADF, Ca, and total glucosinolates. The content of $\mathrm{CF}$ and ash were also quite variable. The DM content of 13 DLRSM averaged $89.78 \%$, ranged from $88.71-90.66 \%$. On a DM basis, the total glucosinolates content $(\mu \mathrm{mol} / \mathrm{g})$ ranged from $4.15-22.73$ with an average of 10.07 .

\section{Exp. 1: Energy digestibility}

The ATTD of GE, the DE and ME and ME:DE ratio of the 13 DLRSM are presented in Table 7. There were no differences in these values among the different DLRSM. On a DM basis, the DE content of the DLRSM varied by $483 \mathrm{kcal} / \mathrm{kg}$ and ranged from $2616-3099 \mathrm{kcal} / \mathrm{kg}$; the 
Table 7 Energy concentration and apparent total tract digestibility (ATTD) of GE of double-low rapeseed meals fed to growing pigs (Exp. 1, DM basis)

\begin{tabular}{|c|c|c|c|c|}
\hline Item & ATTD of GE, \% & $\mathrm{DE}, \mathrm{kcal} / \mathrm{kg}$ & $\mathrm{ME}, \mathrm{kcal} / \mathrm{kg}$ & ME/DE, \% \\
\hline \multicolumn{5}{|l|}{ Number $^{a}$} \\
\hline 1 & 65.81 & 3011 & 2921 & 97.41 \\
\hline 2 & 63.20 & 2887 & 2720 & 94.16 \\
\hline 3 & 64.65 & 2936 & 2814 & 95.88 \\
\hline 4 & 58.86 & 2729 & 2534 & 92.58 \\
\hline 5 & 58.35 & 2675 & 2522 & 93.84 \\
\hline 6 & 61.44 & 2892 & 2769 & 95.50 \\
\hline 7 & 61.99 & 2882 & 2689 & 92.97 \\
\hline 8 & 57.41 & 2616 & 2537 & 97.05 \\
\hline 9 & 58.24 & 2620 & 2514 & 95.59 \\
\hline 10 & 64.16 & 2943 & 2819 & 95.23 \\
\hline 11 & 61.58 & 2828 & 2733 & 96.64 \\
\hline 12 & 66.58 & 3093 & 2964 & 95.83 \\
\hline 13 & 68.75 & 3099 & 2868 & 91.70 \\
\hline SEM & 3.32 & 151.51 & 173.75 & 2.42 \\
\hline Mean & 62.39 & 2862 & 2723 & 94.95 \\
\hline Maximum & 68.75 & 3099 & 2964 & 97.41 \\
\hline Minimum & 57.41 & 2616 & 2514 & 91.70 \\
\hline $\mathrm{CV}^{\mathrm{b}}$ & 5.69 & 5.69 & 5.74 & 1.87 \\
\hline$P$-value & 0.31 & 0.30 & 0.63 & 0.88 \\
\hline
\end{tabular}

${ }^{\mathrm{a}}$ Sources of double-low rapeseed meal are described in Table 1

${ }^{\mathrm{b}} \mathrm{CV}$ coefficient of variation

ME content of the DLRSM varied by $450 \mathrm{kcal} / \mathrm{kg}$ and ranged from $2514-2964 \mathrm{kcal} / \mathrm{kg}$. The ATTD of GE and the ME:DE ratio averaged 62.39 and $94.95 \%$, with a range of $57.41-68.75 \%$, and $91.70-97.41 \%$, respectively.

\section{Exp. 2: Amino acid digestibility}

The data on one of the 10 DLRSM (DLRSM number 13) was considered an outlier because the value was more than three standard deviations away from the mean [24]. Therefore, only 9 of the 10 DLRSM are discussed here. The chemical composition of the DLRSM (numbers $1-5,8,10-12$ ) is shown in Table 2, and their AA content (\%) is shown in Table 3. As expected, the AA content of DLRSM varied among samples especially for Lys and Met. The level (\%) of CP ranged from 40.29-43.64 with an average of 42.40 on a DM basis. The concentrations of Lys and Met of DLRSM ranged from 1.94-2.41 \% and 0.76-1.00 \% with an average of $2.09 \%$ and $0.90 \%$, respectively.

Tables 8 and 9 show the AID and SID values of CP and AA, respectively. There were no significant differences in the AID of CP and AA (except for Lys) among different DLRSM, but the largest variation among indispensable AA was Lys, and among dispensable AA was
Pro. Also there were no significant differences in the SID of CP and AA (except for Lys) among different DLRSM, the largest variation among indispensable AA was for Lys, and among the dispensable AA, the greatest variation was observed for Pro. The AID values of Lys ranged from $60.41-68.53 \%$ with an average of $63.85 \%$, and SID values ranged from $68.69-76.72 \%$ with an average value of $72.81 \%$.

\section{Discussion}

The objectives of this study were to investigate the variation of the chemical composition, energy content and ileal AA digestibility of DLRSM. The pigs used in the two experiments remained healthy and had no feed refusals throughout the experiment.

The chemical composition and AA content of DLRSM varied among samples, which may be due to different double-low rapeseed sources and processing techniques [1]. All DLRSM samples used in this experiment were solvent-extracted Brassica napus, but there may be considerable variation in the temperatures used during double-low rapeseed processing. From Table 2, it appears that the total glucosinolates content varied among samples, which may be a result of differences among varieties of rapeseeds. It is also possible that other cruciferous crops caused cross pollination in the double low rapeseeds and thereby reduced the quality. Variation in the oil content among DLRSM $(0.70-1.98 \%)$ may result from the differences in processing conditions during the oil extraction among different crushing plants. The NDF content of 13 kinds of DLRSM was large and variable, this may be because of different degree of Maillard reactions during desolventization and toasting as reported by Woyengo et al. [5].

The concentration of CP in the 13 DLRSM sources was slightly greater than the values published by Fan et al. [25] and Landero et al. [26], but similar to the values reported by Bell and Keith [27], Xi et al. [11] and Woyengo et al. [5]. The AA composition (except Met and Cys) of the 13 DLRSM sources was slightly lower than the values published by Fan et al. [25], Woyengo et al. [5], and Landero et al. [26], and the NDF content of the 13 DLRSM sources was greater than the values published by these studies, but similar to the values reported by Xi et al. [11], using DLRSM also produced in China. The reason why the NDF content in this study were greater than previously published values may be due to differences in variety, the different analytical methods used [28] or a result of Maillard reactions during desolventization and toasting as reported by Woyengo et al. [5]. In addition, Maillard reactions may have reduced concentrations of AA in DLRSM. That is the reason why the AA composition (except Met and Cys) of the 13 DLRSM sources in the current study were 
Table 8 Apparent ileal digestibility (\%) of AA in double-low rapeseed meals fed to growing pigs (Exp. 2)

\begin{tabular}{|c|c|c|c|c|c|c|c|c|c|c|c|c|c|c|c|}
\hline \multirow[t]{2}{*}{ Item } & \multicolumn{9}{|c|}{ Double-low rapeseed meal number ${ }^{a}$} & \multirow[b]{2}{*}{ SEM } & \multirow[b]{2}{*}{ Mean } & \multirow[b]{2}{*}{ Maximum } & \multirow[b]{2}{*}{ Minimum } & \multirow[b]{2}{*}{$\mathrm{CV}^{\mathrm{b}}$} & \multirow[b]{2}{*}{$P$-value } \\
\hline & 1 & 2 & 3 & 4 & 5 & 8 & 10 & 11 & 12 & & & & & & \\
\hline Crude protein & 61.57 & 60.41 & 62.44 & 67.32 & 66.67 & 60.71 & 63.35 & 63.65 & 68.53 & 1.98 & 63.85 & 68.53 & 60.41 & 4.67 & 0.18 \\
\hline \multicolumn{16}{|c|}{ Indispensable AA } \\
\hline Arg & 79.95 & 82.57 & 79.73 & 82.58 & 80.44 & 77.16 & 78.15 & 77.55 & 80.80 & 1.82 & 79.88 & 82.58 & 77.16 & 2.49 & 0.61 \\
\hline His & 78.61 & 78.95 & 79.69 & 81.92 & 82.22 & 75.51 & 81.02 & 80.62 & 81.00 & 1.36 & 79.95 & 82.22 & 75.51 & 2.59 & 0.17 \\
\hline lle & 73.13 & 76.16 & 74.67 & 74.72 & 74.90 & 71.56 & 76.18 & 73.89 & 75.80 & 2.31 & 74.56 & 76.18 & 71.56 & 2.03 & 0.97 \\
\hline Leu & 73.57 & 76.96 & 75.86 & 76.01 & 75.17 & 71.27 & 74.32 & 73.59 & 75.66 & 2.00 & 74.71 & 76.96 & 71.27 & 2.31 & 0.85 \\
\hline Lys & 62.48 & 65.10 & 65.61 & 71.63 & 69.04 & 62.63 & 67.91 & 63.25 & 73.08 & 1.90 & 66.75 & 73.08 & 62.48 & 5.85 & 0.01 \\
\hline Met & 77.76 & 80.26 & 79.43 & 79.71 & 83.22 & 76.41 & 80.90 & 79.49 & 81.58 & 1.50 & 79.86 & 83.22 & 76.41 & 2.51 & 0.32 \\
\hline Phe & 72.08 & 77.70 & 73.44 & 74.21 & 77.27 & 73.53 & 74.64 & 76.68 & 76.35 & 1.69 & 75.10 & 77.70 & 72.08 & 2.62 & 0.52 \\
\hline Thr & 57.68 & 64.47 & 62.72 & 65.75 & 64.77 & 60.33 & 62.70 & 62.67 & 66.81 & 2.50 & 63.10 & 66.81 & 57.68 & 4.45 & 0.57 \\
\hline Trp & 69.44 & 67.08 & 69.33 & 71.56 & 72.94 & 66.64 & 70.53 & 71.53 & 73.64 & 3.50 & 70.30 & 73.64 & 66.64 & 3.44 & 0.74 \\
\hline Val & 67.45 & 71.68 & 68.48 & 69.61 & 72.62 & 66.48 & 70.50 & 71.66 & 72.91 & 2.74 & 70.15 & 72.91 & 66.48 & 3.28 & 0.48 \\
\hline \multicolumn{16}{|c|}{ Dispensable AA } \\
\hline Ala & 65.55 & 69.75 & 66.14 & 71.26 & 72.15 & 65.28 & 69.26 & 69.40 & 73.48 & 2.04 & 69.14 & 73.48 & 65.28 & 4.27 & 0.23 \\
\hline Asp & 61.78 & 63.91 & 66.89 & 66.73 & 66.14 & 60.42 & 63.90 & 63.28 & 67.62 & 3.55 & 64.52 & 67.62 & 60.42 & 3.85 & 0.62 \\
\hline Cys & 66.78 & 60.72 & 65.15 & 65.76 & 69.31 & 57.82 & 63.98 & 60.76 & 70.15 & 4.55 & 64.49 & 70.15 & 57.82 & 6.38 & 0.26 \\
\hline Glu & 76.60 & 80.66 & 79.38 & 81.47 & 81.70 & 76.66 & 79.12 & 79.95 & 81.86 & 1.73 & 79.71 & 81.86 & 76.60 & 2.51 & 0.22 \\
\hline Gly & 55.26 & 57.12 & 54.06 & 64.67 & 64.26 & 53.30 & 58.27 & 58.20 & 64.78 & 5.12 & 58.88 & 64.78 & 53.30 & 7.80 & 0.17 \\
\hline Pro & 48.74 & 51.95 & 44.28 & 61.23 & 56.24 & 45.30 & 40.05 & 50.26 & 63.92 & 10.32 & 51.33 & 63.92 & 40.05 & 15.44 & 0.19 \\
\hline Ser & 59.98 & 66.46 & 64.59 & 68.15 & 66.61 & 63.13 & 65.63 & 63.72 & 69.24 & 3.64 & 65.28 & 69.24 & 59.98 & 4.29 & 0.50 \\
\hline Tyr & 82.21 & 82.68 & 82.41 & 81.32 & 80.47 & 77.93 & 82.53 & 80.38 & 82.00 & 4.55 & 81.33 & 82.68 & 77.93 & 1.89 & 0.99 \\
\hline
\end{tabular}

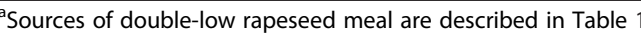

${ }^{\mathrm{b}} \mathrm{CV}$ coefficient of variation

slightly lower and the NDF content was greater than previous data. The greater content of S-containing AA in our DLRSM may due to that the samples in the current study underwent the desolventization and toasting with longer time or higher temperature, because Newkirk et al. [29] reported the desolventization and toasting increased the content of S-containing AA. The content of ether extract in the 13 DLRSM sources was lower than the values reported by Fan et al. [25], NRC [7], Woyengo et al. [5], and Landero et al. [26]. The lower content of ether extract may be due to the improved oil extraction methods for the DLRSM used in this study or due to no gums being added to the meals, which caused a lower GE content.

Though DLRSM is a protein supplement, its available energy content is critical for feed formulation [1]. Although the difference of energy content among DLRSM samples was not significant, the gap between the highest value and the lowest value was so large that it couldn't be ignored during the feed formulation. The difference in energy content among the DLRSM samples may be caused by the different total glucosinolates content, fiber content, and protein content. The reduction of total glucosinolates improves the available energy content of DLRSM [30], and reduced fiber concentration and greater protein concentration increases the concentration of gross energy [1]. The average $\mathrm{DE}$ for the 13 DLRSM ( $2862 \mathrm{kcal} / \mathrm{kg}$ on a DM basis) was lower than the values $(3584 \mathrm{kcal} / \mathrm{kg}$ on a DM basis) reported by NRC [7], but was similar to the DE published by Whittemore et al. [31], and within the range of $\mathrm{DE}$ values $(2581-3346 \mathrm{kcal} / \mathrm{kg}$ on a DM basis) reported by de Lange et al. [32] The mean ME content for DLRSM in the present study $(2723 \mathrm{kcal} / \mathrm{kg}$ on a DM basis) was lower than the value $(3299 \mathrm{kcal} / \mathrm{kg}$ on a DM basis) published by NRC [7] but within the range of ME values $(2701-3497 \mathrm{kcal} / \mathrm{kg}$ on a DM basis) reported by Bell [1]. The lower DE and ME values may be due to lower content of ether extract or greater fiber content of DLRSM used in the current study [1]. The average ME:DE ratio (94.95\%) for the 13 DLRSM agrees with the value reported by Sibbald [33], who concluded that the ME content of DLRSM was $86-96 \%$ of $\mathrm{DE}$ content.

The AID of the essential AA in the present experiment was slightly lower than the values reported in NRC [7] and 
Table 9 Standardized ileal digestibility (\%) of AA in double-low rapeseed meals fed to growing pigs (Exp. 2) $)^{\text {a,b }}$

\begin{tabular}{|c|c|c|c|c|c|c|c|c|c|c|c|c|c|c|c|}
\hline \multirow[t]{2}{*}{ Item } & \multicolumn{9}{|c|}{ Double-low rapeseed meal number ${ }^{a}$} & \multirow[b]{2}{*}{ SEM } & \multirow[b]{2}{*}{ Mean } & \multirow[b]{2}{*}{ Maximum } & \multirow[b]{2}{*}{ Minimum } & \multirow[b]{2}{*}{$\mathrm{CV}^{\mathrm{c}}$} & \multirow[b]{2}{*}{$P$-value } \\
\hline & 1 & 2 & 3 & 4 & 5 & 8 & 10 & 11 & 12 & & & & & & \\
\hline Crude protein & 71.19 & 70.12 & 72.65 & 75.46 & 74.55 & 68.69 & 73.68 & 72.22 & 76.72 & 1.94 & 72.81 & 76.72 & 68.69 & 3.55 & 0.33 \\
\hline \multicolumn{16}{|c|}{ Indispensable AA } \\
\hline $\operatorname{Arg}$ & 87.56 & 89.10 & 87.41 & 87.76 & 86.36 & 83.03 & 86.44 & 84.69 & 86.88 & 1.94 & 86.58 & 89.10 & 83.03 & 2.07 & 0.80 \\
\hline His & 82.74 & 82.56 & 83.99 & 85.07 & 85.34 & 78.69 & 85.32 & 83.98 & 84.36 & 1.51 & 83.56 & 85.34 & 78.69 & 2.50 & 0.28 \\
\hline Ile & 77.03 & 79.71 & 78.71 & 77.61 & 77.80 & 74.42 & 80.39 & 77.05 & 78.72 & 2.38 & 77.94 & 80.39 & 74.42 & 2.24 & 0.94 \\
\hline Leu & 78.38 & 81.28 & 80.83 & 80.08 & 79.47 & 75.48 & 79.44 & 78.27 & 80.04 & 1.64 & 79.25 & 81.28 & 75.48 & 2.18 & 0.65 \\
\hline Lys & 66.71 & 68.72 & 69.64 & 74.97 & 72.45 & 66.54 & 71.92 & 67.16 & 76.54 & 1.70 & 70.52 & 76.54 & 66.54 & 5.20 & 0.01 \\
\hline Met & 80.26 & 82.67 & 81.98 & 82.27 & 85.64 & 79.10 & 83.42 & 82.25 & 84.14 & 1.39 & 82.41 & 85.64 & 79.10 & 2.36 & 0.26 \\
\hline Phe & 76.44 & 81.43 & 78.01 & 78.54 & 81.18 & 77.72 & 79.06 & 80.83 & 80.56 & 1.62 & 79.31 & 81.43 & 76.44 & 2.23 & 0.61 \\
\hline Thr & 65.27 & 70.93 & 70.22 & 71.76 & 70.79 & 66.43 & 70.36 & 69.08 & 73.02 & 2.29 & 69.76 & 73.02 & 65.27 & 3.56 & 0.62 \\
\hline Trp & 75.14 & 72.56 & 75.46 & 76.97 & 77.90 & 71.91 & 76.10 & 76.81 & 78.98 & 2.32 & 75.76 & 78.98 & 71.91 & 3.07 & 0.71 \\
\hline Val & 72.27 & 75.98 & 73.62 & 73.84 & 76.43 & 70.58 & 75.39 & 75.71 & 76.93 & 1.73 & 74.53 & 76.93 & 70.58 & 2.83 & 0.45 \\
\hline \multicolumn{16}{|l|}{ Dispensable AA } \\
\hline Ala & 74.38 & 77.49 & 75.49 & 78.47 & 78.94 & 72.32 & 77.98 & 76.95 & 80.51 & 2.01 & 76.95 & 80.51 & 72.32 & 3.26 & 0.42 \\
\hline Asp & 66.57 & 70.50 & 70.50 & 71.97 & 71.34 & 65.71 & 70.07 & 69.22 & 73.08 & 2.17 & 69.88 & 73.08 & 65.71 & 3.44 & 0.59 \\
\hline Cys & 72.21 & 66.20 & 70.74 & 73.12 & 75.74 & 65.60 & 69.94 & 68.56 & 77.39 & 2.37 & 71.06 & 77.39 & 65.60 & 5.64 & 0.08 \\
\hline Glu & 79.50 & 83.16 & 82.39 & 84.03 & 84.22 & 79.22 & 82.14 & 82.75 & 84.53 & 1.31 & 82.44 & 84.53 & 79.22 & 2.34 & 0.21 \\
\hline Gly & 78.19 & 77.18 & 77.89 & 82.40 & 81.42 & 70.83 & 81.90 & 77.03 & 82.74 & 3.94 & 78.84 & 82.74 & 70.83 & 4.82 & 0.76 \\
\hline Pro & 102.94 & 98.73 & 94.78 & 101.78 & 96.57 & 83.59 & 98.57 & 93.55 & 104.84 & 14.57 & 97.26 & 104.84 & 83.59 & 6.52 & 0.99 \\
\hline Ser & 67.86 & 73.09 & 72.30 & 74.23 & 72.92 & 69.33 & 73.32 & 70.57 & 75.61 & 2.18 & 72.14 & 75.61 & 67.86 & 3.40 & 0.57 \\
\hline Tyr & 89.31 & 89.29 & 89.42 & 85.58 & 85.14 & 82.67 & 90.12 & 85.17 & 86.76 & 2.39 & 87.05 & 90.12 & 82.67 & 2.98 & 0.62 \\
\hline
\end{tabular}

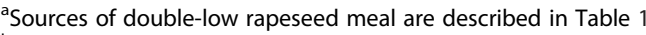

${ }^{b}$ Values for standardized ileal digestibility were calculated by correcting apparent ileal digestibility for the basal endogenous losses. Basal ieal endogenous were determined (g/kg dry matter intake) as crude protein, 15.2; Arg, 0.58; His, 0.16; Ile, 0.24; Leu, 0.50; Lys, 0.31; Met, 0.07; Phe, 0.26; Thr, 0.47; Trp, 0.10; Val, 0.37;

Ala, 0.56; Asp, 0.62; Cys, 0.23; Glu, 0.74; Gly, 1.60; Pro, 4.61; Ser, 0.46; Tyr 0.46

${ }^{\mathrm{C}} \mathrm{CV}$ coefficient of variation

the SID of AA in the present experiment was slightly lower than the values reported by previous research $[34,35]$. The decreased AA digestibility for DLRSM used in current study may be due to Maillard reaction that occurred during the desolventization and toasting process or the high fiber concentration in the DLRSM $[1,5]$. During processing of DLRSM, a temperature of $80-90{ }^{\circ} \mathrm{C}$ is necessary to denature myrosinase $[1,9]$. However, the temperature used in the stage of cooking, prepressing, desolventizing and toasting in actual production is usually higher than $100{ }^{\circ} \mathrm{C}$. This level of heat may lead to Maillard reactions, which will result in reduced AA concentration $[1,36]$. This may be also a factor for the difference of AID and SID values of Lys among the DLRSM samples in the present study.

In conclusion, there was variability in chemical composition especially the concentration of EE, NDF and ADF, but no significant differences in energy content of the DLRSM samples. In addition, the AID and SID of Lys vary among the DLRSM samples, but for most other AA, the AID and SID are relatively similar among different samples. Future work should be conducted to identify the relationship between the chemical composition and the nutritional value and determine the effects of the individual steps of process procedure on the energy content and AA digestibility in the DLRSM.

\section{Abbreviations}

AA: Amino acid; ADF: Acid detergent fiber; AID: Apparent ileal digestibility; ATTD: Apparent total tract digestibility; BW: Body weight; CP: crude protein; CF: Crude fiber; CV: Coefficient of variation; DE: Digestible energy;

DLRSM: Double-low rapeseed meal; EE: Ether extract; GE: Gross energy; ME: Metabolizable energy; NDF: Neutral detergent fiber; SEM: Standard error of the mean; SID: Standard ileal digestibility.

\section{Competing interests}

The authors declare that they have no competing interests.

\section{Authors' contributions}

FLW and PLL carried out the experiment trial, performed the statistics and drafted the manuscript. FW participated animal trial. JRW, LL and CHL conceived the study, and participated in its design and coordination. All authors read and approved the final manuscript.

\section{Acknowledgements}

This research was financially supported by the Modern Agricultural Industry Technology System (CARS-36) and Special Public Sector Fund in Agriculture (200903006). 


\section{Author details}

'State Key Laboratory of Animal Nutrition, College of Animal Science and Technology, China Agricultural University, Beijing 100193, China. ${ }^{2}$ College of Bio-engineering, Henan University of Technology, Zhengzhou 450001, Henan, China.

Received: 2 April 2015 Accepted: 9 July 2015

Published online: 21 August 2015

\section{References}

1. Bell JM. Factors affecting the nutritional value of canola meal: a review. Can J Anim Sci. 1993;73:689-97.

2. Bell JM, Keith MO, Hutcheson DS. Nutritional evaluation of very low glucosinolate canola meal. Can J Anim Sci. 1991;71:497-506.

3. Sauer WC, Cichon R, Misir R. Amino-acid availability and protein-quality of canola and rapeseed meal for pigs and rats. J Anim Sci. 1982;54:292-301.

4. Han YK, Kim IH, Hong JW, Kwon OS, Lee SH, Kim JH, et al. Apparent ileal digestibility of nutrient in plant protein feedstuffs for finishing pigs. Asian Australas J Anim Sci. 2003;16:1020-4.

5. Woyengo TA, Kiarie E, Nyachoti CM. Energy and amino acid utilization in expeller-extracted canola meal fed to growing pigs. J Anim Sci. 2010:88:1433-41.

6. Eklund M, Caine WR, Sauer WC, Huang GS, Diebold G, Schollenberger M, et al. True and standardized ileal digestibilities and specific ileal endogenous recoveries of crude protein and amino acid in soybean meal, rapeseed meal and peas fed to growing pigs. Livest Sci. 2012;145:174-82.

7. NRC. Nutrient requirements of swine. 11th ed. Washington: National Academies Press; 2012

8. Almeida FN, Htoo JK, Thomson J, Stein HH. Effects of heat treatment on the apparent and standardized ileal digestibility of amino acids in canola meal fed to growing pigs. Anim Feed Sci Technol. 2014;187:44-52.

9. Canola Council of Canada. Canola Meal Feed Industry Guide, 4th ed. http://www.canolacouncil.org/media/516716/canola_meal_feed_guide_ english.pdf. Accessed 17 Oct 2013.

10. Li DF, Xi PB, Gong LM, Fan SJ, Huang CH. Determination of apparent ileal amino acid digestibility in rapeseed meal and cake processed at different temperatures using the direct and difference method with growing pigs. Arch Anim Nutr. 2002:56:339-49.

11. Xi PB, Li DF, Gong LM. Ileal amino acid digestibility in different cultivars of Chinese rapeseed meals for growing-finishing pigs. Asian Australas J Anim Sci. 2002;15:1326-33.

12. Zhang T, Liu L, Piao XS. Predicting the digestible energy of rapeseed meal from its chemical composition in growing-finishing pigs. Asian Australas J Anim Sci. 2012;25:375-81.

13. Adeola. Digestion and balance techniques in pigs. In: Lewis AJ, Southern LL, editors. Swine nutrition. New York: CRC Press; 2001. p. 903-16.

14. Song GL, Li DF, Piao XS, Chi F, Yang WJ. Apparent ileal digestibility of amino acids and the digestible and metabolizable energy content of high-oil corn varieties and its effects on growth performance of pigs. Arch Anim Nutr. 2003:57:297-306.

15. Ren P, Zhu Z, Dong B, Zang J, Gong L. Determination of energy and amino acid digestibility in growing pigs fed corn distillers' dried grains with solubles containing different lipid levels. Arch Anim Nutr. 2011;65:303-19.

16. Stein HH, Seve B, Fuller MF, Moughan PJ, de Lange CFM. Invited review: Amino acid bioavailability and digestibility in pig feed ingredients: Terminology and application. J Anim Sci. 2007:85:172-80.

17. Stein HH, Shipley CF, Easter RA. Technical note: A technique for inserting a T-cannula into the distal ileum of pregnant sows. J Anim Sci. 1998;76:1433-6.

18. AOAC. Official methods of analysis. 18th ed. Arlington: Association of Official Analytical Chemists; 2006

19. Thiex NJ, Anderson S, Gildemeister B. Crude fat, diethyl ether extraction, in feed, cereal grain, and forage (Randall/Soxtec/submersion method): collaborative study. J Aoac Int. 2003:86:888-98.

20. Thiex NJ, Manson H, Anderson S, Persson J. Determination of crude protein in animal feed, forage, grain, and oilseeds by using block digestion with a copper catalyst and steam distillation into boric acid: collaborative study. J Aoac Int. 2002:85:309-17.

21. Van Soest PJ, Robertson JB, Lewis BA. Methods for dietary fiber, neutral detergent fiber, and nonstarch polysaccharides in relation to animal nutrition. J Dairy Sci. 1991;74:3583-97.
22. Daun JK, Mcgregor DI. Glucosinolate analysis of rapeseed (canola), Method of the Canadian grain commission grain research laboratory. Winnipeg: Canadian Grain Commission; 1983.

23. Ji Y, Zuo L, Wang F, Li D, Lai C. Nutritional value of 15 corn gluten meals for growing pigs: chemical composition, energy content and amino acid digestibility. Arch Anim Nutr. 2012;66:283-302

24. Urriola PE, Stein $\mathrm{HH}$. Effects of distillers dried grains with solubles on amino acid, energy, and fiber digestibility and on hindgut fermentation of dietary fiber in a corn-soybean meal diet fed to growing pigs. J Anim Sci. 2010;88:1454-62

25. Fan MZ, Sauer WC, Gabert VM. Variability of apparent ileal amino acid digestibility in canola meal for growing-finishing pigs. Can J Anim Sci. 1996;76:563-9.

26. Landero JL, Beltranena E, Cervantes M, Morales A, Zijlstra RT. The effect of feeding solvent-extracted canola meal on growth performance and diet nutrient digestibility in weaned pigs. Anim Feed Sci Technol. 2011:170:136-40.

27. Bell JM, Keith MO. A survey of variation in the chemical-composition of commercial canola-meal produced in western canadian crushing plants. Can J Anim Sci. 1991;71:469-80.

28. Cozannet P, Primot Y, Gady C, Metayer JP, Lessire M, Skiba F, et al. Energy value of wheat distillers grains with solubles for growing pigs and adult sows. J Anim Sci. 2010;88:2382-92.

29. Newkirk RW, Classen HL, Scott TA, Edney MJ. The digestibility and content of amino acids in toasted and non-toasted canola meals. Can J Anim Sci. 2003:83:131-9.

30. Kawakishi S, Kaneko T. Interactions of proteins with allyl isothiocyanate. J Agr Food Chem. 1987;35:85-8.

31. Whittemore CT, Hazzledine MJ, Close WH. Nutrient Requirement Standards for Pigs. Penicuik: BSAS; 2003.

32. de Lange C, Gabert VM, Gillis D, Patience JF. Digestible energy contents and apparent ileal amino acid digestibilities in regular or partial mechanically dehulled canola meal samples fed to growing pigs. Can J Anim Sci. 1998;78:641-8

33. Sibbald IR. The TME system of feed evaluation: Methodology, feed composition data and bibliography, Research branch. Ottawa: Agriculture Canada; 1986.

34. Noblet J, Le Goff G. Effect of dietary fibre on the energy value of feeds for pigs. Anim Feed Sci Technol. 2001;90:35-52.

35. Maison T, Stein HH. Digestibility by growing pigs of amino acids in canola meal from North America and 00-rapeseed meal and 00-rapeseed expellers from Europe. J Anim Sci. 2014:92:3502-14

36. Classen HL, Newkirk RW, Maenz DD. Effects of conventional and novel processing on the feed value of canola meal for poultry. Proc Aust Poult Sci Symposium. 2004;16:1-8

\section{Submit your next manuscript to BioMed Central and take full advantage of:}

- Convenient online submission

- Thorough peer review

- No space constraints or color figure charges

- Immediate publication on acceptance

- Inclusion in PubMed, CAS, Scopus and Google Scholar

- Research which is freely available for redistribution 